\title{
Different Point of View to the Autoimmune Diseases and Treatment with Acupuncture
}

\section{Betül Battaloğlu İnanç*}

Family Medicine Department, Faculty of Medicine, Muğla Sıtkı Koçman University, Muğla, Turkey

Received May 5, 2020

Reviewed June 18, 2020

Accepted November 27, 2020

\section{*Corresponding Author}

Betül Battaloğlu İnanç

Family Medicine Department, Faculty of Medicine, Muğla Sıtkı Koçman University, Aydın Muğla Yolu No:43, 48000 Gülağzı/ Muğla, Turkey

Tel: +90-252-214-1326,27,28/5195

E-mail: betulbattaloglu00@gmail.com
Objectives: It was aimed to investigate the basic action mechanism of the autoimmune diseases and common features of all diseases. Autoimmune disease are classified organ specific and systemic.

Methods: These diseases are seen systemic and disease start locations, origins seem differently. This makes learning and understanding difficult. Autoimmune diseases investigated for easier understanding. It was noticed that, autoimmune diseases' starting places are specific and same all of them. This remarkable point is very important for acupuncture also. So; whole literatüre was researched and important point was found.

Results: Whole autoimmune diseases are attack to mesodermal layers and mesodermal origin organs of the body's. The common property of all these disease are same; Diseases start from the mesoderm and mesodermal layer even though their organ origins' belongs to different germ layer. From this point of view, we were able to classify autoimmune diseases simply and it was planned how can we effect body in this context with acupuncture. Conclusion: And, when immunity comes into question, induction of adaptive immunity is depend on antigen presentation to T cells and this situation take place in the lymph node (LN) and also in the skin.When we sank the acupuncture needle into skin, signals create and start mesodermal contacts, during this time mesenchymal origin' autoimmune cells are regulated with this signals.

Keywords: autoimmunity, mesoderm, ectoderm, skin, acupuncture, inflamation, immunmodulation

\section{INTRODUCTION}

Distinguish between self and non-self is extremely important for the body immune system. Any breakdown about this mechanism steps can start autoimmune diseases in the body [1]. Because, braken down body tolerance responds could be causes autoimmunity defects and this may lead to group of autoimmune diseases. It occurs in $5-10 \%$ of the population in autoimmune diseases [2,3], these diseases were previously divided into "organ-specific" and "non-organ-specific", but on later different perspectives also developed and used in the classifications (Table 1). The frequency of autoimmune diseases worldwide is very diverse. In the studies show, that the first region such as Europe, North America, Australia, New Zealand and the second region such as Asia, Middle East, Caribbean, South America are
Table 1. The original classification of autoimmune diseases into organ-specific and non-organ-specific

\begin{tabular}{ll}
\hline \multicolumn{1}{c}{ Organ-specific } & \multicolumn{1}{c}{ Non-organ-specific } \\
\hline $\begin{array}{l}\text { Hashimoto's thyroiditis } \\
\text { Graves' disease }\end{array}$ & $\begin{array}{c}\text { Sjögren's syndrome } \\
\text { APECED (autoimmune polyendocrinopathy- } \\
\text { candidiasis ectodermal dystrophy) }\end{array}$ \\
\hline $\begin{array}{l}\text { Pernicious anaemia } \\
\text { Rheumatoid arthritis }\end{array}$ \\
$\begin{array}{l}\text { Addison's disease } \\
\text { Myasthenia gravis }\end{array}$ \\
$\begin{array}{l}\text { Type 1 diabetes } \\
\text { Multiple sclerosis }\end{array}$ \\
\hline
\end{tabular}

autoimmune diseases frequency and also appearance of organ spesific autoimmune diseases are different too. These autoimmune diseases are $85 \%$ higher in males than females [4]. As we 
have seen, we are confronted with a disease group which is also prevalent.When we look at these tables, we almost see illnesses involve every organ. Affected region and organs are so common in the body, but is there a joint point belong the diseases? And do this highlighted point be affected by acupuncture? If this point were affected with acupuncture, is it possible to contribute the treatment? Because, since 1997, ulcerative colitis's patients could treat with acupuncture, and the researchers thought that therapy this treatment is by regulating abnormal T lymphocyte subgroups and that autoimmunity also improves [5]. Thus, the idea that autoimmunity can be modified by acupuncture seems likely. As everyone has said, Is this tail? Or is it possible? I thougt that it is possible. And, this original article was planned and researched. Autoimmunity starting mechanism was investigated and explain acupuncture's effects on them.

\section{MATERIALS AND METHODS}

Autoimmune disease are clasified two: Organ specific and systemic. And, origin places of the diseases are so common and different. This situation makes learning and understanding being difficult.And It was researched with different pespective that these disases could be more understandabl and could be more easier.First of all, we ask questions and try to explain these, because, there is no article in the publications yet the existence of such a trick point presence; How do we classificate autoimmune systeme diseases very simply? And, we want to see a general rules for autoimmune disases. And, we researched autoimmune diseases progression. We noticed, autoimmun diseases' starting places are spesific and same all of them. And we explained these. This remarkable point is very important for acupuncture also.

Well, if we could look at autoimmüne diseases with embriological perpective, could we get to reach somewhere? Let us see. From the endodermal layer; epithelial lining of the gastrointestinal tract, respiratory tract, tympanic cavity, auditory tube, urinary bladder, and parenchymas of thyroid, parathyroids, liver, and pancreas are developed [6].

From the mesodermal layer; vascular system, urogenital system (except the bladder), spleen and cortex of the suprarenal glands cortexes, liver, hematopoietic cells, Kupffer cells, connective tissue cells and muscular system develops [6]. And dermis occurs from mesoderm.

Central and peripheral nervous system, subcutaneous and mammary glands, and pituitary gland, and enamel of the teeth are developed from the ectodermal layer also [6]. Being remembered this embryological development, autoimmune diseases possible clasification would be more understandable.

\section{RESULTS}

What we said? Autoimmun diseases' starting places are spesific and same all of them. And all of them is starting from mesodermal layer. This is a detail that we noticed and highligtened. Therefore, in particulary here (for example, non-mesodermal organs such as thyroid, stomach, colon) will be addressed. It is obvious that the other autoimmune disease starting sites are the mesodermal layer (Table 2).

\section{Hashimoto's thyroiditis}

First of all, thyroid is an organ of develops from endodermal origin [6]. Autoimmune thyroid disease (AITD) is one of the most common autoimmune disorder. Anti-thyroid peroxidase (TPO), anti-thyroglobulin (Tg), and anti-thyroid-stimulating hormone receptor (TSHR) antibodies are mostly seen. More rarely, antibodies to thyroid antigens such as Carbonic anhydrase 2, megalin, T3 and T4, sodium iodide symporter (NIS) and pendrin can also be seen [4].

It is seen that, the disease is developing against the receptor, not for the organ. This nuance differences may not seen important. But embryologically these details are important. Because, disease start at the receptor's level and receptors are mesodermal layer origins structures. This is so important. Thyroid disease is, namely endodermal organ's disease is belong to mesodermal origin layer's receptor disturbance. So, antibodies occure to against the mesodermal layer. Antibodies don't act to against to endodermal organs cells. Yes, organ function could change, but there is not an direct attack to destroy organ cells. This is an important description. Thus, these antibodies change the signal transmission pathway we thought.

\section{Graves' disease}

It is an autoimmune thyroid disease that occurs with symptoms of hyperthyroidism. Accelerated thyroid metabolism, higher thyroid peroxidase (TPO) activity, excess thyroglobulin (Tg) release, increased iodine clearance from plasma and reduced iodine retention are typical mechanisms. Symptoms can often be seen after emotional trauma [4]. 
Different Point of View to the Autoimmune Diseases and Treatment with Acupuncture

Table 2. Some common autoimmune diseases classified by immunopathogenic mechanism

\begin{tabular}{|c|c|c|}
\hline Syndrome & Autoantigen & Consequence \\
\hline \multicolumn{3}{|l|}{ Type II antibodytocell-surface or matrix antigens } \\
\hline Autoimmune hemolytic anemia & Rh blood group antigens, I antigen & $\begin{array}{l}\text { Desruction of red blood cells by } \\
\text { complementand FcR+ phagocytes, anemia }\end{array}$ \\
\hline Autoimmune thromboytopenic purpura & Platelet integrin, Gpllb;IIla & Abnormal bleeding \\
\hline Good pasture's syndrome & $\begin{array}{l}\text { Non collagenous domain of basement } \\
\text { membrane collagen type IV }\end{array}$ & Glomerulonephritis, pulmoner hemorrhage \\
\hline Acute rheumatic fever & $\begin{array}{l}\text { Streptecocal cell-wall antigens. Antibodies } \\
\text { cross-react with cardiac muscle }\end{array}$ & $\begin{array}{l}\text { Artritis, myocarditis, lates carring of hearth } \\
\text { valves }\end{array}$ \\
\hline \multicolumn{3}{|l|}{ Type III immunec omplex disease } \\
\hline Mixed essential cryoglobulinemia & $\begin{array}{l}\text { Rheumatoid factor lgG complexes (With or } \\
\text { without hepatitis } C \text { antigens) }\end{array}$ & Systemic vasculitis \\
\hline \multicolumn{3}{|l|}{ Type IV T cell-mediated disease } \\
\hline Insulin-dependent diabetes mellitus & Pancreatic $\beta$-cellantigen & $\beta$-cell desruction \\
\hline Rheumatoid artritis & Unknownsnovialjointantigen & Joint inflamation and destruction \\
\hline $\begin{array}{l}\text { Experimental autoimmune encephalomyelitis } \\
\text { (EAE), multiple sclerosis }\end{array}$ & $\begin{array}{l}\text { Myelin basic protein, proteolipid protein, myelin } \\
\text { oligodendro cyteglicoprotein }\end{array}$ & Brain invasion by $C D+T$ cells, weakness \\
\hline
\end{tabular}

In Graves' disease (GD), there is antibody against thyroid stimulating hormone receptor (TSHR) [7]. It is identified as an immunoglobulin $\mathrm{G}$ and was subsequently confirmed to be an antibody against TSHR. These antibodies have known effects on fibroblasts also [7]. Due to the long-term effect of this antibody, it has been called the long-acting thyroid stimulator (LATS) [4]. And, this antibody structures were design by proteins [6]. And once again it is seen that antibodies were designed by proteins and these proteins structure were also mesodermal part of the body. Because, first event always start with attack to the receptors level and mesodermal layer was consumed first.

\section{Autoimmune gastritis and pernicious anaemia}

There may be difficulties in the histopathological diagnosis of autoimmune gastritis (AG). But, the real histological criterion are include; Lamina propria mononuclear cell infiltrate, foci without oxintic glands, intestinal metaplasia (IM), pyloric metaplasia and parietal cell pseudohypertrophy [8]. The frequency of pernicious anemia increases after the age of 60 . The initial change is the infiltration of the oxintic mucosa by lymphocytes and plasma cells. The unstable destruction of parietal cells, occasional protected oxintic mucosa are appeared differently The reduction or loss of hydrochloric acid secretion leads to; loss of oxintic mucosa, impaired maturation of parietal cells, and decrase selective binding of anti-parietal cell antibodies to $\mathrm{H}+$ / $\mathrm{K}+$ ATPase [9]. Although, the stomach is an endodermal layer origin' organ, starting foci of destruction area is mononuclear infiltrate within the lamina propria. Lamina propria is a layer of mesodermal origin also [6]. And, anti-parietal cell antibodies consist of. Initiating disease' depend on oxyntic mucosa's destroy and anti parietal cell antibodies occur. These parts, which initiate the disease, are the mesodermal layer components.

\section{Multiple sclerosis}

Multiple sclerosis (MS) is a demyelinating and neurodegenerative autoimmune disease of the central nervous system [10]. Although the etiology is not clear, but genetic, environmental and infectious agents are thought to be effective in the onset and development of the disease [11].

Myelin basic protein (MBP) is essential in MS pathology. MBP contains the myelin sheath necessary for normal activity of the nervous system. Also, Tau protein is a marker of in many neurological diseases, including MS. Tau protein is thought to spread among synaptically linked neurons through its release 
out of the cell in a prion-like manner [10]. In addition, autoreactive T cells are thought to cause MS. The important roles of B cells in MS pathogenesis are also highlighted by clinical and immunological observations [11]. Although, the central nervous system creates to ectodermal layer. But, as we have seen, pathologic process is starting against to $\mathrm{MBP}$ and Tau proteins. Histological process origins start against to mesodermal structures; Proteins, receptors, ....And, these are part of the mesodermal layers structures embriologically also.

\section{Inflammatory bowel diseases}

Ulcerative colitis and Crohn's diseases are continue to rise in low-incidence areas such as Southern Europe and Asia, except in places where the incidence and prevalence are high, such as North Europe and North America. Prevalence is increasing. Ulcerative colitis (UC) is one of the major forms of inflammatory bowel disease (IBD). Chronic inflammation and continuous involvement of the colon mucosa is characteristic [12]. Severe chronic inflammation always involves basal plasmacytosis in Lamina propria. Typical findings of ulcerative colitis are characterized by a common mucosal inflammatory infiltrate and crypt destruction. This is a plasma cell infiltration into the lower third of the lamina propyrium, just above the muscularis mucosa and between the crypt base. Basal plasmacytosis occurs in all forms of chronic colitis, it is important for the diagnosis of IBD, it is especially useful to distinguish it from infective colitis. Quiet disease is characterized by the lack of mucosal neutrophils [13]. As we have seen, pathological origins process are starting from muscularis mucosae, lamina propria. And, these structures are mesodermal layer components also. The cells involved in infiltration are mesodermal component too.

\section{DISCUSSION}

As we have seen, mesodermal layer destroy by the antibod- ies. How could we help these diseases with acupuncture? Is it possible. Yes.

First of all. Priciples of Yin and Yang. Because, this symbolic discribing show us an important point. Balance. And, acupuncture treatment basement is "Be stable Yin, Protect Yang". Do we stable Yin. Of course, yes.

The skin is the largest organ in the body. Epidermis develops from surface ectoderm; dermis develops from mesenchyme [6]. With interactions between cells and tissues, organs are formed. This interaction is epithelial-mesenchymal interaction [6]. Best epidermal- mesenchymal interactions happen at this level. And, we prick to needle into skin, our needle goes from epidermis into dermis and hypodermal layer. So, this meaning is when we prick the needle into skin, epidermal-mesenchymal interactions starts, and ectodermal-mesodermal activation starts. Why this subject important? Particularly in the context of this paragraph, two autoimmune process-mediated molecules have been identified.

First, Transforming growth factor beta (TGF-beta) is a secreted protein that regulates proliferation, differentiation and death of various cell types. All immune cell lineages (thrombocytes, notrophilles, lymphosites, including B, T and dendritic cells, macrophages), secrete TGF-beta. As seen, TGF-beta is a potent, important, immunosuppressor. Disturbance of TGFbeta effects is caused to autoimmunity, inflammation and cancer [14].

Second, The identification of Langerhans cells on the skin is more recent. Dentritic cells; it controls B and T lymphocytes. It captures and processes antigens, releases lymphocyte costimulating molecules, releasing cytokines. They minimize autoimmune reactions. So, in many cases where immune control is required, they are actually the target cells [15]. Both of these cell types that we mentioned have epidermis and dermis. Also present in keratinocyte, melanocyte, langerhans cells, fibrositis, must cells and macrophages. We could see keratinocytes and melanocytes functionin Table 3.

Table 3. Selected hormone and neurotransmitter receptors expressed in keratinocytes and melanocytes

\begin{tabular}{cc}
\hline Cell type & Receptor repertoire \\
\hline Keratinocytes & CRH-R1, MC1-R, $\mu$ - and $\zeta$-opioid-R, PRL-R, LH/CG-R, GH-R, CGRP-R, VIP-R, neurokinin-R, class II PTH/PTHrP-R, vitamin D-R, \\
& androgen-R, estrogen-R, glucocorticoid-R, mineralocorticoid-R, muscarinic-R, nicotinic-R, adrenoreceptors, glutamate-R, \\
& gastrin-releasingpeptide-R, NPY-R, purinoreceptors, $H_{1}$ and $\mathrm{H}_{2}$ histamine-R, somatostatin-R (?), bombesin-R, (?) \\
Melanocytes & CRH-R1, MC1-R, LH/CG-R, GH-R, CGRP-R, VIP-R, vitamin D-R, androgen-R estrogen-R, glucocorticoid-R, adrenoreceptors, \\
& muscarinic-R, $\mathrm{H}_{2}$ histamine-R \\
\hline
\end{tabular}

$\mathrm{R}$, receptor; (?), possible expression. 
The acupuncture studies show some parts of the system autoimmunity too. When needle sank into skin, skin cells and skin mediators, like dendritic cells or TGF beta could be activate also we thought. While the cells were activated immune modulation regulate too. In addition that acupuncture effect mechanisms was shown under the following steps in the publications during the years; Acupuncture stimulates natural killer cell activity, modulates Th1 / Th2 balance, reduces apoptosis, increases lymphokinine-induced killer cytotoxic activity. Regulation of biochemical synergy between electroacupuncture and neurotrophin (NGF), mobilization of corticosterone, endorphins and adrenocorticotropic hormones (ACTH). Pro-inflammatory and anti-inflammatory effects and modifiying all immune cells by acupuncture. The increase in the release of endogenous opioid peptides is a step that affects the immune system and can be done with acupuncture. And also; From a pharmacological perspective, the dopaminergic effects of acupuncture suggest that it will be effective in the anti-inflammatory process. Because dopamine secretion increases with acupuncture [16-20].

Is it possible to do all these checks from the skin? Yes, We insert the needle into skin. And we stimulate ectodermal and mesodermal layer. And we damaged skin, cells come this area for regeneration, and we stimulate skin's receptors, also we give stimulus whole ectodermal and mesodermal embryonic mentioned organs. Skin effect process (Table 4-6) [21, 22].

\section{CONCLUSION}

When immunity comes into question, whole cells but especially, antigen presentation to $\mathrm{T}$ cells is essential for immunity. And this happens not only in the lymph node, inside the body, but also it happens at the skin that is the outermost barrier of the body. When skin-homing effector memory $\mathrm{T}$ cells stimulate, they are chancing some properties and they are becoming like the central memory T cells. And they present their function with modifiying. In addition, these cells move back and forth between the skin and related LNs [23].

As we have seen; Autoimmune diseases, start from the mesodermal points and these diseses are treat with creating ectodermal-mesodermal signal transmission by sinking needle into skin, and there are lots of clinical trials prove the treatment possible with acupuncture for autoimmunity.

How could succeed acupuncture that treatment? We create signals with recalling that all autoimmune cells are mesodermal origin and we are regulated the mesodermal signals with mesodermal cells again. So being stabilized the Yin with the needle. In other word create mesodermal remodelling and healing process. As we defined earlier Yin; We think that it represents the mesodermal layer and Mesodermal layer seems so important. If you think about it, you'll see that even drugs do the mechanisms of action through the mesodermal cell and layer. If you activate mesoderm like defined as the nature of Yin (improver, the producer, self, etc...), you contribute to the treatment. And when we sink the needle, we reach ectoderm and mesoderm.

Table 4. Selected hormones and neurotransmitters produced in the skin

\begin{tabular}{lc}
\hline \multicolumn{1}{c}{ Compartment } & \multicolumn{1}{c}{ Hormones and neurotransmitter repertoire } \\
\hline Epidermis & Vitamin D, PTHrP, androgens, $\mathrm{T}_{3}, \mathrm{~L}$-DOPA, catecholamines, acetylcholine, serotonin, glutamate, aspartate, CRH, \\
& urocortin, $\alpha-, \beta-, \gamma$-MSH, ACTH, $\beta$-endorphin, enkephalins, TRH \\
Dermis and adnexal & Vitamin D, PTHrP, estrogens, androgens, L-DOPA, serotonin, glutamate, aspartate, CRH, urocortin, $\alpha-, \beta-, \gamma-\mathrm{MSH}$, \\
structures & $\mathrm{ACTH}, \beta$-endorphin, enkephalins, GH, histaminecatecholamines*, acetylcholine* \\
\hline
\end{tabular}

*In the dermis, catecholamines and acetylcholine originate predominantly from cutaneous nevre endings.

Table 5. Selected neuropeptides generated in the skin

\begin{tabular}{ll}
\hline \multicolumn{1}{c|}{ Source } & \multicolumn{1}{c}{ Neuropeptide } \\
\hline $\begin{array}{l}\text { Resident and circulating } \\
\text { skin cells }\end{array}$ & $\begin{array}{c}\text { Gastrin-releasingpeptide, somatostatin, NPY, atrialnatriureticpeptide, PHM/PHI, galanin, neurokinins, substance P, } \\
\text { neurotensin, CGRP, VIP, bradikinin, cholecystokinin, endothelins, CRH, urocortin, } \alpha-, \beta-, \gamma-\mathrm{MSH}, \mathrm{ACTH}, \beta \text {-endorphin, } \\
\text { enkephalins } \\
\text { Nerve endings }\end{array}$ \\
$\begin{array}{l}\text { Substance P, neurokinins, neurotensin, CGRP, VIP, somatostatin, NPY, atrialnatriureticpeptide, gastrin-releasing } \\
\text { peptide PHM/PHI, bradikinin, galanin, cholecystokinin, endothelins, } \alpha-, \gamma \text {-MSH, } \beta \text {-endorphin, CRH, urocortin, } \\
\text { dynorphin, enkephalins }\end{array}$ \\
\hline
\end{tabular}


Table 6. Major stres mediators in skin

\begin{tabular}{|c|c|c|c|}
\hline Stress mediator & Source & Effector cell & Funtions in skin \\
\hline $\mathrm{CRH}$ & $\begin{array}{l}\text { Hypotalamus, Skin keratinocytes, } \\
\text { sebacytes, and must cells }\end{array}$ & $\begin{array}{l}\text { CRH-R1 is expressed in epidermis, } \\
\text { dermis and subcutis layer; CRH-R2 } \\
\text { is expressed in hair follicle } \\
\text { keratinoyctes and papilla fibroblasts }\end{array}$ & $\begin{array}{l}\text { Stimulation of downstream ACTH and } \\
\text { cortisol production; Proliferation, } \\
\text { differantiation, apoptosis, inflamation, } \\
\text { and angiogenesis. }\end{array}$ \\
\hline ACTH & $\begin{array}{l}\text { Pituitary gland; } \\
\text { Skin melanocytes, epidermal } \\
\text { and hair follicle keratinocytes } \\
\text { and dermal fibroblasts; } \\
\text { Langerhans cells, monocytes, and } \\
\text { macrophages }\end{array}$ & $\begin{array}{l}\text { MC2-R is expressed in skin } \\
\text { melanocytes, hair follicles, epidermal } \\
\text { keratinocytes, sebaceous and ecrine } \\
\text { glands, as well as dermal fibroblasts, } \\
\text { sebaceous and ecrine glands, } \\
\text { muscle and dermal blood vessels }\end{array}$ & $\begin{array}{l}\text { Stimulation of cortisol and cortocosterone } \\
\text { production; } \\
\text { Melanogenesis, cytokine production, } \\
\text { cell proliferation, dendritic formation, } \\
\text { hair growth, immune and inflammation } \\
\text { regulation. }\end{array}$ \\
\hline Cortisol & $\begin{array}{l}\text { Adrenal cortex; Skin hair follicles, } \\
\text { melanocytes, and fibroblasts }\end{array}$ & $\begin{array}{l}\text { Glucocorticoids receptor is ubiquitous } \\
\text { expressed in all skin cells }\end{array}$ & $\begin{array}{l}\text { Major impact on the immun and } \\
\text { inflamation system; Cell proliferation } \\
\text { and survival via the PI3K/Akt } \\
\text { pathway; Hair follicle proliferation } \\
\text { and differantiation; Epidermal barrier } \\
\text { formation }\end{array}$ \\
\hline Neurotrophins & $\begin{array}{l}\text { Central nervous system; } \\
\text { Skin sympathetic neurons, } \\
\text { mastcells, T-cells and B-cells, } \\
\text { keratinocytes, fibroblasts, and } \\
\text { melanocytes }\end{array}$ & $\begin{array}{l}\text { Two receptors TrK and p } 75 \text { are } \\
\text { expressed in mast cells, immune } \\
\text { cells, keratinocytes, fibroblasts and } \\
\text { melanocytes }\end{array}$ & $\begin{array}{l}\text { Promote skin innervations; } \\
\text { Promote survival and differentiation of } \\
\text { mast cells, and modify inflammatory } \\
\text { cytokines expressions; } \\
\text { Promote proliferation of keratinocytes; } \\
\text { Important for melanocytes migration, } \\
\text { viability and differentiation and } \\
\text { protect them from oxidative stres and } \\
\text { apoptosis; } \\
\text { Promote fibroblast differentiation and } \\
\text { migration, and possibly contraction and } \\
\text { MMP secretion. }\end{array}$ \\
\hline Substance P & Sensory nevre fibers & Mustcells, macrophages, T-cells & $\begin{array}{l}\text { Cytokine release to induce inflammation, } \\
\text { active must cells, and induce lymphocyt } \\
\text { eproliferation induce vascular } \\
\text { permeability }\end{array}$ \\
\hline Prolactin & $\begin{array}{l}\text { Pituitary gland; } \\
\text { Skin hair follicle and } \\
\text { epidermalkeratinocytes, } \\
\text { fibroblasts, adipocytes, } \\
\text { sweatglands, and } \\
\text { sebaceousglands }\end{array}$ & $\begin{array}{l}\text { Prolactin receptor is ubiquitous } \\
\text { expressed except in fibroblasts }\end{array}$ & $\begin{array}{l}\text { Autocrine hair growth modulator by } \\
\text { promoting catagen (hair regression); } \\
\text { Stimulate keratinocytes growth and } \\
\text { keratin production in keratinocytes; } \\
\text { Sebum production in sebaceous glands; } \\
\text { Immuno-modulation. }\end{array}$ \\
\hline $\begin{array}{l}\text { Catecholamines } \\
\text { (Epinephrine and } \\
\text { norepinephrine) }\end{array}$ & $\begin{array}{l}\text { Adrenal medulla; Skin nevre fibers, } \\
\text { keratinocytes }\end{array}$ & $\begin{array}{l}\text { Adrenergic receptors are expressed by } \\
\text { natural killer cells, monocytes, and T } \\
\text { cells, keratinocytes andmelanocytes }\end{array}$ & $\begin{array}{l}\text { Regulate keratinocytes proliferation, } \\
\text { differantiation, and migration; Promote } \\
\text { melanogenesis in melanocytes; } \\
\text { Decrease fibroblasts migration and } \\
\text { collagen secretion and impair wound } \\
\text { healing; Suppress IL-12' in dentritic } \\
\text { cells leading to blunthed T h1 and } \\
\text { increased T h2 differantation; Important } \\
\text { for lymphocyte trafficking, circulation, } \\
\text { proliferation, andcytokine production. }\end{array}$ \\
\hline
\end{tabular}

PI3K/Akt, phosphoinositide 3-kinase/Akt (alsoknown as protein kinase B or PKB); Th, T hepler; IL, interleukin. 
And body it responds aganist this with self-balancing. So some sort of reset. The duration may be long, but it seems so clear that we contribute to the pathologies of mesoderm tissues by acupuncture.

\section{CONFLICT OF INTEREST}

No competing interest was declared by the author.

\section{FUNDING}

No external funding sources were used for this study.

\section{ORCID}

Betül Battaloğlu İnanç, https://orcid.org/0000-0001-7478-5451

\section{REFERENCES}

1. Simmonds MJ, Gough SCL. Genetic insights into disease mechanisms of autoimmunity. Br Med Bull. 2005;71(1):93-113.

2. Becker KG. Comparative genetics of type 1 diabetes and autoimmune disease: common loci, common pathways? Diabetes. 1999;48(7):1353-8.

3. Vyse TJ, Todd JA. Genetic analysis of autoimmune disease. Cell. 1996;85(3):311-8.

4. Fröhlich E, Wahl R. Thyroid autoimmunity: role of anti-thyroid antibodies in thyroid and extra-thyroidal diseases. Front Immunol. 2017;8:521.

5. Wu H, Chen H, Hua X, Shi Z, Zhang L, Chen J. Clinical therapeutic effect of drug-separated moxibustion on chronic diarrhea and its immunologic mechanisms. J Tradit Chin Med. 1997;17(4):253-8.

6. Sadler TW, Langman J. Langman's medical embryology. 12th ed. Philadelphia: Wolters Kluwer Health/Lippincott Williams \& Wilkin; 2012. p. 50-110.

7. Adams DD, Purves HD. Abnormal response in the assay of thyrotropin. Proc Univ Otago Med Sch. 1956;34:11-2.

8. Chlumská A, Boudová L, Benes Z, Zámecník M. Autoimmune gastritis. A clinicopathologic study of 25 cases. Cesk Patol. 2005; 41(4):137-42.

9. Minalyan A, Benhammou JN, Artashesyan A, Lewis MS, Piseg- na JR. Autoimmune atrophic gastritis: current perspectives. Clin Exp Gastroenterol. 2017;10:19-27.

10. Derkus B, Acar Bozkurt P, Tulu M, Emregul KC, Yucesan C, Emregul E. Simultaneous quantification of Myelin Basic Protein and Tau proteins in cerebrospinal fluid and serum of Multiple Sclerosis patients using nanoimmunosensor. Biosens Bioelectron. 2017;89(Pt 2):781-8.

11. Bail K, Notz Q, Rovituso DM, Schampel A, Wunsch M, Koeniger T, et al. Differential effects of FTY720 on the B cell compartment in a mouse model of multiple sclerosis. J Neuroinflammation. 2017;14(1):148.

12. Loftus EV Jr. Clinical epidemiology of inflammatory bowel disease: incidence, prevalence, and environmental influences. Gastroenterology. 2004;126(6):1504-17.

13. Bryant RV, Winer S, Travis SP, Riddell RH. Systematic review: histological remission in inflammatory bowel disease. Is 'complete' remission the new treatment paradigm? An IOIBD initiative. J Crohns Colitis. 2014;8(12):1582-97.

14. Moustakas A, Pardali K, Gaal A, Heldin CH. Mechanisms of TGF-beta signaling in regulation of cell growth and differentiation. Immunol Lett. 2002;82(1-2):85-91.

15. Banchereau J, Steinman RM. Dendritic cells and the control of immunity. Nature. 1998;392(6673):245-52.

16. Kim SK, Bae H. Acupuncture and immune modulation. Auton Neurosci. 2010;157(1-2):38-41.

17. Takahashi T, Sumino H, Kanda T, Yamaguchi N. Acupuncture modifies immune cells. J Exp Clin Med. 2009;1(1):17-22.

18. Torres-Rosas R, Yehia G, Peña G, Mishra P, del Rocio Thompson-Bonilla M, Moreno-Eutimio MA, et al. Dopamine mediates vagal modulation of the immune system by electroacupuncture. Nat Med. 2014;20(3):291-5.

19. Silverio-Lopes S, da Mota MPG. Acupuncture in modulation of immunity. In: Chen LL, Cheng TO, editors. Acupuncture in modern medicine. London: InTech; 2013. p. 51-76.

20. Cabioğlu MT, Cetin BE. Acupuncture and immunomodulation. Am J Chin Med. 2008;36(1):25-36.

21. Chen Y, Lyga J. Brain-skin connection: stress, inflammation and skin aging. Inflamm Allergy Drug Targets. 2014;13(3):177-90.

22. Slominski A, Wortsman J. Neuroendocrinology of the skin. Endocr Rev. 2000;21(5):457-87.

23. Egawa G, Kabashima K. Skin as a peripheral lymphoid organ: revisiting the concept of skin-associated lymphoid tissues. J Invest Dermatol. 2011;131(11):2178-85. 